P-ISSN: 2774-4574; E-ISSN: 2774-4582

TRILOGI, 2(3), September-Desember 2021 (375-381)

@2021 Lembaga Penerbitan, Penelitian, dan Pengabdian kepada Masyarakat (LP3M) Universitas Nurul Jadid Paiton Probolinggo

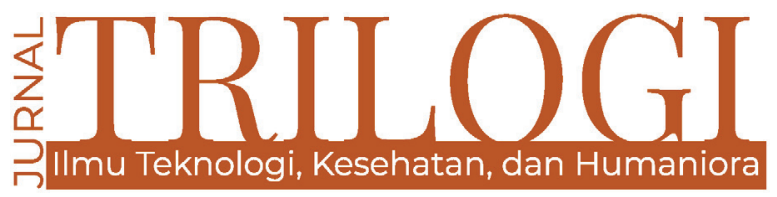

\title{
STRATEGI PENGELOLAAN BELANJA SANTRIWATI MELALUI E-BEKAL DI PONDOK PESANTREN NURUL JADID WILAYAH AL-HASYIMIYAH
}

\section{Sofian Syaiful Rizal}

Universitas Nurul Jadid

sofiansyaifulrizal@unuja.ac.id

\author{
Hanifatul Qomariyah \\ Universitas Nurul Jadid \\ merry.assyifa91@gmail.com
}

\section{Fenti Nur Aisyah}

Universitas Nurul Jadid

fentinuraisyah81@gmail.com

\begin{abstract}
This study aims to determine the strategy for managing student spending at the Nurul Jadid Islamic Boarding School in the Al-Hasyimiyah Region, the E-Bekal Santri application or the Santri Study Card has just been issued by the Nurul Jadid Islamic Boarding School in collaboration with Bank Negara Indonesia (BNI) Syariah and PT TKI ( Indonesian Card Technology). In this case, it can help make it easier for Wali Santri to control the finances of students in their daily lives. This study uses a descriptive qualitative method based on observations, interviews. The data techniques are data collection, data reduction, data presentation and conclusion drawing or verification. The results of this study indicate that: 1) the E-Bekal program can make it easier for guardians of santri to control the finances of santri 2) It can reduce cases of money loss (theft/lost tucked away) in PP. Nurul Jadid Al-Hasyimiyah Region, in this case the launch of the E-Bekal Program, is an answer from the Islamic boarding school for input from the Wali Santri, in addition to providing convenience for the Wali Santri. The E-Bekal program also minimizes unwanted negative things in managing student spending in the millennial era with the use of modern technology.
\end{abstract}

Keywords: Management Strategy, Student Shopping, E-Supplies Card 


\begin{abstract}
Abstrak
Penelitian ini bertujuan untuk mengetahui strategi pengelolaan belanja santriwati di Pondok Pesantren Nurul Jadid Wilayah Al-Hasyimiyah, aplikasi E-Bekal Santriwati baru saja dikeluarkan Pondok Pesantren Nurul Jadid yang bekerja sama dengan Bank Negara Indonesia (BNI) Syariah dan PT TKI (Teknologi Kartu Indonesia). Dalam hal ini dapat membantu memudahkan Wali Santri untuk mengontrol keuangan santri dalam kesehariannya begitu pula permasalahan kehilangan uang yang selalu dikeluhkan oleh santri dapat di minimalisir dengan kartu ebekal ini. Studi ini menggunakan metode kualitatif deskriptif berdasarkan observasi, interview. Adapun teknik datanya yaitu pengumpulan data, reduksi data, penyajian data dan penarikan kesimpulan atau verifikasi. Hasil penelitian ini menunjukkan bahwa: 1) Program E-Bekal dapat memudahkan Wali Santri untuk mengontrol keuangan santri 2) Dapat mengurangi kasus kehilangan uang (pencurian/hilang terselip) di PP. Nurul Jadid Wilayah Al-Hasyimiyah. dalam hal ini peluncuran Program E-Bekal merupakan jawaban dari pihak pesantren atas masukan dari Wali Santri, disamping memberikan kemudahan untuk para Wali Santri. Program E-Bekal juga meminimalisir hal negative yang tidak di inginkan dalam pengelolaan belanja Santriwati di era milenial dengan penggunaan teknologi modern.
\end{abstract}

Katakunci: Strategi Pengelolaan, Belanja Santriwati, Kartu E-Bekal

\section{Pendahuluan}

Pondok Pesantren Nurul Jadid Paiton Probolinggo merupakan lembaga pendidikan pesantren yang didirikan oleh almarhum $\mathrm{KH}$. Zaini Mun'im. Kehadiran Pondok Pesantren Nurul Jadid secara perlahan mampu merubah tata kehidupan masyarakat sekitar. Berkat ketekunan $\mathrm{KH}$. Zaini Mun'im bersama santri-santrinya, masyarakat disadarkan akan pentingnya agama dalam kehidupan sehari-hari (Wahidah, 2015).

Pondok Pesantren adalah cikal bakal institusi pendidikan Islam di Indonesia. Pesantren dikenal sebagai lembaga pendidikan Islam tertua di Indonesia. Kehadiran awal pesantren diperkirakan dari abad 300-400 tahun lalu dan menjangkau hampir semua tingkat komunitas Muslim Indonesia (Fadli,2012), khususnya di Jawa. Kesuksesan pesantren dalam mencetak generasi emas tidak terlepas dari metode pendidikan yang menjawab tantangan zaman. Pesantren Nurul jadid adalah salah satu pondok pesantren terbesar setapal kuda yang nampaknya mendapat pengakuan yang cukup luas dikalangan masyarakat (Syahroni,2018). Terbukti dengan makin banyaknya jumlah santri yang berdatangan dari segala penjuru tanah air, bahkan dari luar negeri (Singapura dan Malaysia). Karena banyaknnya santri dari berbagai waliyah dan latar belakang yang berbeda sehingga pesantren membutuhkan aplikasi untuk menampung berbagai transaksi keuangan santri secara efisien sehingga mucul gagasan E-Bekal sebagai aplikasi mobile untuk mempermudah wali santri
Pondok Pesantren Nurul Jadid dalam melakukan pembayaran kos makan santri, pengiriman bekal belanja harian santri, sehingga santri langsung dapat melakukan transaksi secara non tunai di area Pondok Pesantren Nurul Jadid (Bashori,2017).

Era digital telah membawa masyarakat ke arah yang lebih maju dan modern. Hal ini didukung oleh kehadiran teknologi Financial Technologi (Fintech). Fintech merupakan inovasi yang dihasilkan oleh industri digital di baidang pelayanan jasa keuangan. Fintech yang di Indonesia terdiri dari berbagai jenis, salah satunya adalah pembayaran non tunai dengan menggunakan uang elektronik atau e-money (Adiyanti, 2015).

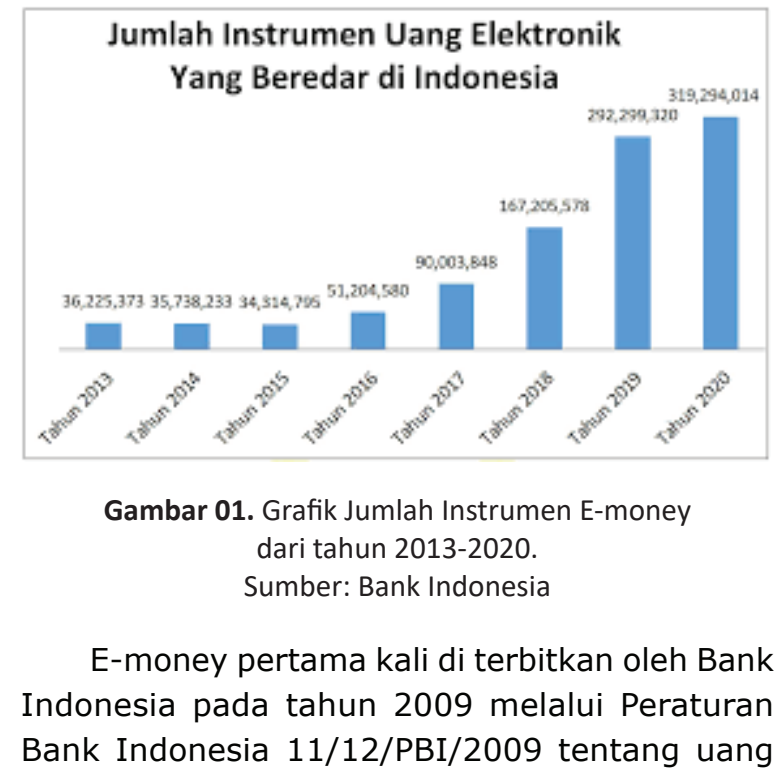


elektronik (e-money). (Pranoto \& Salsabila, 2018) Menurut Nisa Salsabila e-money menjadi salah satu Gerakan Nasional Non Tunai (GNNT) pada awal Agustus 2014, melalui gerakan inilah perkembangan e-money hingga kini terus meningkat. Dari data yang diperoleh dari Bank Indonesia, kini instrumen e-money pada bulan Oktober 2018 tecatat 144.361.292 instrumen (Syahroni,2018).

Salah satu faktor yang memicu peningkatan penggunaan e-money di Indonesia adalah Gerakan Nasional Non Tunai (GNNT). Melalui gerakan ini BI (Bank Indonesia) menggandeng beberapa lembaga, salah satunya adalah pesantren. Pesantren yang menjadi uji coba penggunaan e-money adalah pesantren Daaruut Tauhiid, Bandung Jawa Barat dan pondok pesantren Al-Mawaddah Jawa Timur, (Damanhuri Zuhri, 2015). Selain Pondok Daruut Tauhiid, BI juga menggandeng Pesantren Tebuireng Jombang untuk mengampanyekan penggunaan uang elektronik (e-money) dalam transaksi keuangan di lingkungan pesantren (Fathoni, 2016). Hal ini juga disambut baik oleh Pesantren Sunan Pandanaran, Sardonoharjo, pada 17 November 2015 lalu. Pesantren ini mewajibkan santrinya yang berjumlah kurang lebih 3.000 santri menggunakan e-money dalam bertransaksi (Aksami, 2019).

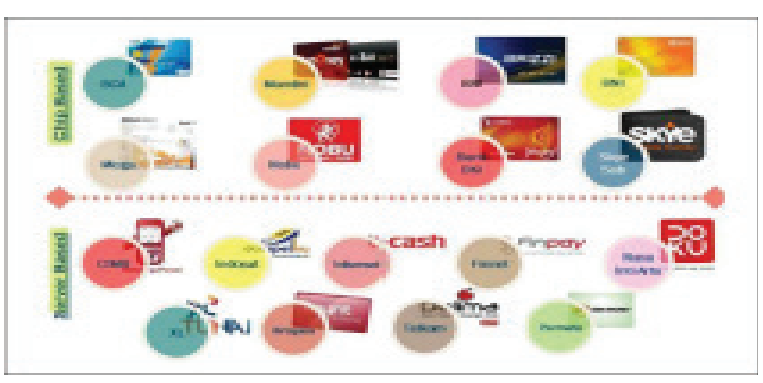

Gambar 02. Produk-Produk E-Money di Indonesia Sumber: Bank Indonesia

Penggunaan e-money juga dapat diakses melaui ponsel. Layanan ini diterbitkan oleh perusahaan telekomunikasi dan perbankan. Caranya dengan menggunakan nomor ponsel sebagai nomor rekening. Beberapa produk yang diterbitkan oleh perusahaan telekomunikasi antara lain, Telkomsel dengan layanan T-Cash, XI Axiata dengan XI Tunaiku dan i-Vas Card dari Telkom serta Dompetku Ooredoo dari Indosat. Produk e-money perbankan misalnya layanan rekening ponsel dari layanan Mandiri, Bank CIMB Niaga, E-Cash dari Bank Mandiri, (Bank Indonesia, 2006).

Era digital telah membawa masyarakat ke arah yang lebih maju dan modern (Fitri,2020). Dalam hal ini di tandai dengan semakin merebaknya kecanggihan-kecanggihan teknologi yang menjadikan dunia nyata beralih ke dunia maya (Dzikrulloh, 2018). Semenjak tahun 2017 Pondok Pesantren Nurul Jadid menerapkan layanan keuangan digital dan transaksi e-money (Fathoni,2016). Dalam Transaksi Layanan Keuangan Digital (LDK) dapat digunakan untuk pembayaran kos makan santri, pembayaran SPP sekolah dan kampus serta pembayaran yang lainnya. Namun penerapan transaksi e-money sebagai kartu belanja santri masih belum diterapkan secara menyeluruh di lingkungan Pesantren Nurul Jadid. Penerapan transaksi e-money ini hanya di pondok putri Wilayah AlHasyimiyah yang saaat ini menjadi percobaan (Nadiyah N. S., 2021).

Dalam masa pandemi Covid-19 ini Wali santri tidak diperkenankan untuk mengunjungi para Santri dipondok dikarenakan masih dalam masa lockdown (Siahaan, 2020), sejak bualn Juli 2020 pengurus pusat bagian pengembangan bekerja sama dengan bagian bidang usaha untuk memecahkan solusi untuk mempermudah Wali Santri mengirim uang belanja pada putra putrinya, dengan ini muncullah SBS (Simpanan Bekal Santri) yang berguna untuk menyimpan uang belanja santri akan tetapi program ini masih belum menggunakan card. Para pengurus merumuskan kembali program SBS ini dengan semaksimal mungkin agar bisa mencapai cita cita pesantren untuk meningkatkan kualitas pelayanan pesantren dalam transaksi non tunai. Pada tanggal 1 November 2020 pesantren meluncurkan kartu E-Bekal Santri untuk memudah kan para Wali Santri dalam hal mengirim uang belanja putra putrinya di masa pandemi ini, akan tetapi program ini hanya di terap kan di 3 wilayah yakni Al-Hasyimiyah, Az-Zainiyah dan Wilayah Putra Pusat (Yaqin, 2021).

Penelitian ini bertujuan untuk mengurangi hal-hal negative yang masih di alami dalam perjalan program ini dan meberikan solusi untuk setiap masalah yang dihadapi selama berjalannya prograaam E-Bekal ini khususnya di wilayah Al-Hasyimiyah. Peneliti tertarik memilih penelitian di wilayah tertentu (wil. Al-hasyimiyah) karena wilayah Al-Hasimiyah ini pertama kali percobaan dalam penerapan ebekal santriwati di pondok pesantren nurul jadid untuk mengetahui sejauhmana efektifitas penggunakan ebekal santriwati dalam berbelanja, simpanan santri, kesiapan elektronik di masing-masing koperasi 
daltim dll. yang nantinya akan di terapkan oleh semua wilayah satriwati di pondok pesantren nurul jadid, begitu pula wilayah alhasyimiyah ini adalah wilayah yang sudah lengkap beserta kantor dan administrasi untuk e-bekal santriwati yang dinamakan dengan WADIATULMAAL di Wilayah Al-Hasyimiyah.

\section{Metode}

Metode analisis yang digunakan adalah metode kualitatif deskriptif berdasarkan observasi, interview (Rizal, 2021). Penelitian ini bertempat di Wilayah Al-Hasyimiyah Pondok Pesantren Nurul Jadid Paiton Probolinggo. dalam penelitian ini dilaksanakan dalam kurun waktu 4 bulan (Maret - Juni 2021) yang dilaksanakan oleh tiga orang peneliti, satu selaku koordinator dan yang lain sebagai anggotanya. Pendekatan penelitian menggunakan metode fenomenologi dengan teknik pengumpulan data berupa observasi lapangan yaitu melihat kejadiaan social secara langsung untuk bisa mendapatkan kesimpulan sementara tentang objek penelitian dan selanjutnya melakukan interview kepada pihak-pihak yang berkaitan seperti kepala bidang usaha pusat, bendahara wilayah putri wilayah Al-Hasyimiyah, ketua bagian wadiatulmaal di Wilayah Al-Hasyimiyah, sebagai sumber data pendukung peneliti menambahkan beberapa refrensi yang didaptkan dari berbagai buku yang relevan, begitupula diperoleh dari karya tulis ilmiah, jurnal bereputasi dan berita terkait dengan E-Bekal (Suib, 2017).

\section{Hasil dan Pembahasan}

Pondok pesantren Nurul Jadid menerapkan layanan keuangan digital dan transaksi e-money sejak awal tahun 2017. Transaksi Layanan Keuangan Digital (LKD) digunakan untuk pembayaran kos makan, pembayaran uang SPP sekolah dan kampus serta pembayaranpembayaran yang lain. Namun penerapan transaksi e-money sebagai kartu belanja santri masih belum diterapkan secara menyeluruh di lingkungan pesantren Nurul Jadid. Saat ini yang menjadi percobaan penerapan transaksi e-money hanya di pondok putri wilayah Al-Hasyimiyah (Fatimah, 2019).

Setelah sukses dalam penerapan e-money di wilayah Al-Hasyimiyah lalu di terapkan ke 2 wilayah berikutnya di pondok pesantren nurul jadid yaitu wilayah putra pusat dan wilayah az-zainiyah (putri). Adapun penerapan kartu E-Bekal ini sejak tanggal 1 November 2020 dalam penerapan di 3 wilayah yaitu: 1 . Wilayah Al-Hasyimiyah 2. Wilayah Az-zainiyah (Putri) 3. Wilayah putra pusat. Transaksi menggunakan E-Bekal ini masih belum menyeluruh, hanya ada 3 wilayah yang menerapkan program tersebut (Rodiyah, 2021). setelah efesien dan sudah efektif dalam penerapan e-bekal di 3 wilayah tersebut sehingga pada saat inipun tahun 2021 sudah di terapkan kartu ebekal di seluruh wilayah pondok pesantren nurul jadid berbasis E-Bekal dalam simpanan dan belanja santri. Dengan adanya E-Bekal ini pesantren akan lebih mudah melakukan kontroling keuangan santri serta kos makan santri, transaksi lebih mudah, cepat dan praktis. Hal ini sesuai dengan misi pesantren untuk mengambangkan menejemen pesantren yang efektif dan efisien (Faizin, 2015).

Tujuan lain penerapan E-Bekal sebagai bentuk dari pengaplikasian tradisi dan ideologi dasar pesantren Nurul Jadid yaitu dengan adanya Trilogi Santri dan Panca Kesadaran Santri. Panca kesadaran santri yaitu kesadaran beragama, kesadaran berilmu, kedaran berbangsa dan beragama, serta kesadaran berorganisasi. Penerapan E-Bekal di Pondok Pesantren Nurul Jadid merupakan pengaplikasian dari panca kesadaran santri yaitu kesadaran berorganisasi. Dalam mencapai sebuah tujuan pesantren memerlukan pihak lain untuk mewujudkannya. Sinergitas pesantren dengan perbankan merupakan simbiosis mutialisme atau saling memberikan pengaruh positif (Tazkiyyaturrohmah, 2018).

Dalam keadaan pandemi seperti saat ini, adanya E-Bekal sangat membantu memudahkan para Wali Santri dan para Santri dalam transaksi kesehariannya. Motivasi adanya E-Bekal ini yaitu, untuk memudahkan Wali Santri dan merealisasikan cita-cita pesantren dalam segi manajemen keuangan

\section{Mekanisme penerapan E-Bekal di Nurul Jadid}

Pondok Pesantren Nurul Jadid melakukan kerja sama dengan Bank Negara Indonesia (BNI) Syariah dan PT TKI (Teknologi Kartu Indonesia) dengan menggunakan system berbasis Pedatren (Pengelolaan data pesantren) dan terhubung dengan Handphone Wali Santri dengan menggunakan aplikasi Bekal Santri NJ, sehingga Wali Santri dapat mengetahui perkembangan keuangan anaknya setiap harinya (Ghufron, 2021). 


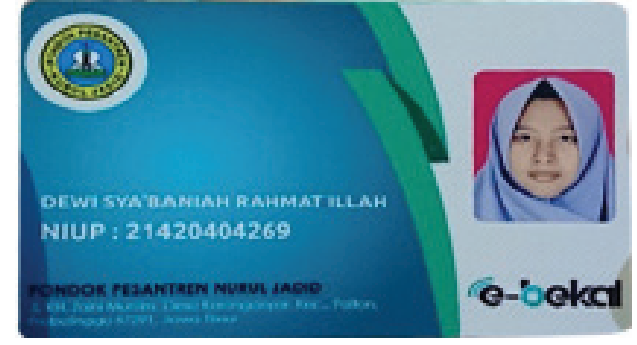

Gambar 03. Kartu E-Bekal Santriwati Pondok pesantren Nurul Jadid

Penerapan E-Bekal di Pesantren Nurul Jadid Wilayah Al-Hasyimiyah melalui beberapa tahapan yaitu: pertama, pengurus menyebarkan kartu E-Bekal pada seluruh sabtri, kemudian menyebarkan virtual account masising santri sebagai penggant nomer rekening yang sudah di berikan pengurus pusat untuk para wali santri, kedua, pengurus pesantren melakukan sosialisasi kepada Wali Santri, Wali Asuh dan Santri bahwa system pembayaran tunai di ganti dengan transaksi non tunai menggunakan kartu E-Bekal dan cara penggunaan aplikasi Bekal Santri NJ kepada Wali Santri, tahap ketiga, pengurus melakukan sosialisasi kepada seluruh pedagang dalam transaksi penggunaan handphone khusus E-Bekal dan cara pengunaannya, keempat, pengurus menyebarkan handphone khusus untuk transaksi kepada seluruh pedagang, kelima, pengurus bagian IT menghubungkan jaringan internet di seluruh koprasi (Ghufron, 2021).

Prosedur Wali Santri dalam melakukan pengiriman uang bulanan dan belanja santri sebagai berikut: 1. Login aplikasi Bekal Santri $\mathrm{NJ}, 2$. Buka menu isi ulang untuk mengetahui nomor rekening (VA), 3. Lakukan pembayaran di teller bank, ATM, Mobile Banking dan juga bisa di lakukan di Gerai Enje Mart 2, 4. Setelah sukses pembayaran akan muncul notifikasi melalui handphone Wali Santri, 5. Setiap transaksi setoran atau pembayaran ke VA melalui jaringan bank, akan dikenakan biaya Rp. 3000 (tiga ribu rupiah) (Nadiyah A. H., 2021).

Santi juga bisa melakukan Cash Out dengan dengan kentuan bahwa santri akan berhenti dari pondok, mempunyai kepentingan di luar pesantren dan melakukan pembayaran di klinik pesantren. Dikarenakan kartu E-Bekal Santri ini tidak bisa di gunakan diluar pesantren.

\section{Fungsi fleksibel dari E-Bekal}

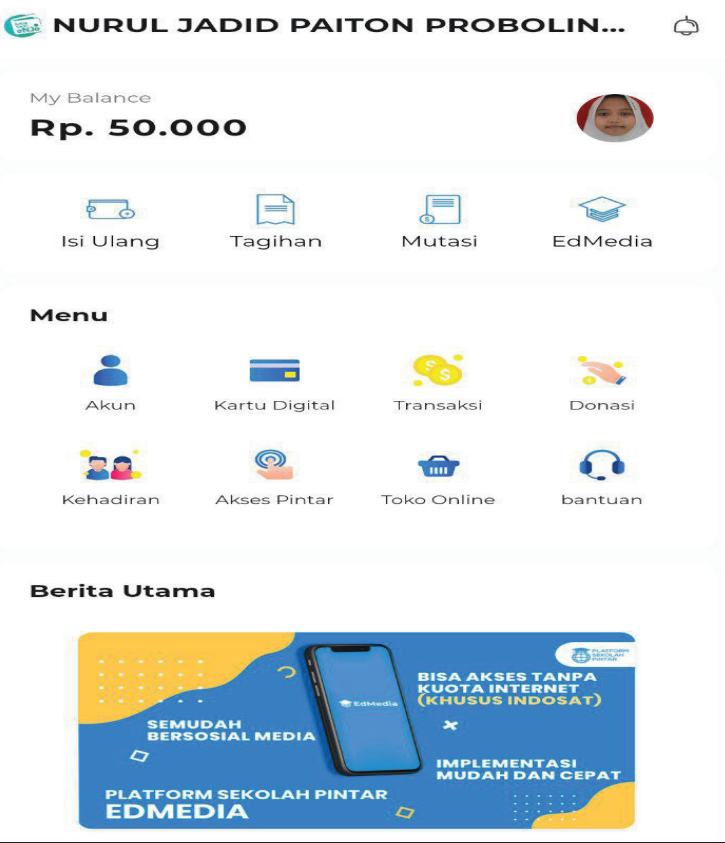

Gambar 04. Tampilan layar depan E-Bekal di aplikasi HP android

Fungsi pertama dari adanya E-Bekal ini adalah untuk transaksi pembayaran kos makan santri yang langsung terkontrol otomatis saat Wali Santri menstranfer uang bulanan santri melalui E-Bekal dengan hal ini dapat mengurangi tingkat penunggakan santri dalam membayar kos makan santri (Salsabila, 2018). Yang kedua adalah sebagai simpanan uang belanja santri yang akan terpantau langsung oleh Wali Santri setiap harinya dan juga wali santri dapat memanajemen jatah perhari santri sesuai dengan kebutuhan dengan mengubah limit kartu sesuai dengan yang di tentukan masing-masing Wali santri untuk jatah anaknya setiap harinya, dengan ini juga bisa mengurangi tingkat keborosan santri dalam berbelanja dan juga bisa belajar mandiri memenejemen keuangan (Faizin, 2015).

\section{Kelebihan E-Bekal}

Kelebihan E-Bekal untuk para santri adalah santri hanya membawa 1 kartu untuk melakukan transaksi tanpa harus membawa berlembarlembar uang tinggal scan pada handphone khusus E-Bekal setelah itu transaksi selesai, dengan adanya e-bekal ini dapat meminimalisir kehilangan uang para santri yang sering terjadi kehilangan sebelum adanya e-bekal ini (W.Asuh, 2021).

Kelebihan E-Bekal untuk kantin adalah dapat meminimalisir adanya kecurangan pedagang terhadap kantin, juga dapat mengetahui 
pendapatan kantin tanpa ada data yang di manipulasi sehingga pendataan pengeluaran secara otomatis bisa diketahui oleh pihak kantin, selain itu pesantren juga mendapat gambaran potensi keuangan pesantren dengan adanya program ini dan juga mengetahui pengeluaran pesantren dengan data, dan juga terkontrolnya masalah kos makan santri. Wali Santri juga bisa memantau kegiatan anaknya melalui aplikasi Bekal Santri NJ yang dapat dilihat melalui icon informasi dalam aplikasi ini sebagai mengetahui portal informasi dan berita dalam pondok pesantren nurul jadid (Nahrawi, 2021).

\section{Kendala penerapan E-Bekal di Nurul Jadid}

Dalam penerapan E-Bekal ini masih belum maksimal, ada beberapa kendala yang menghambat penerapan E-Bekal yaitu: (1) dalam segi kartu hanya bisa di gunakan dalam lingkup pesantren tidak bisa di gunakan di luar pesantren, (2) mengalami masalah dalam jaringan internet (padam, internet eror) dikarenakan transaksi ini harus menggunakan jaringan internet untuk tersambung dalam aplikasi katalis yang terdapat di handphone khusus E-Bekal, (3) sumber daya pedagang yang masih kurang paham menggunakan handphone sebagai alat transaksi (4) kehilangan kartu karena kelalaian santri dalam menjaga kartu nya, (5) wali santri yang gagap teknologi karena harus memantau keuangan santri melalui aplikasi. Dalam kendala yang terjadi ini pengurus bagian bidang usaha berusaha optimal untuk melaksanakan program E-Bekal ini agar lebih maksimal kembali dengan di bantu oleh bagian-bagian terkait seperti tim bagian IT untuk memaksimalkan jaringan internet dan juga bantuan dari pihak bank untuk mengevaluasi adanya kartu E-Bekal ini (Izza, 2021).

\section{Penutup}

Pengelolaan belanja santriwati melalui e-bekal ini sangat bermanfaat dan membantu dalam banyak pihak terutama dalam hal keuangan pesantren yang lebih terkontrol dan mempunyai gambaran keuangan serta mengetahui pengeluaran pesantren dengan data. Dan juga dapat membantu Wali Santri mengontrol keuangan anaknya setiap harinya tanpa harus berkunjung ke pesantren dalam masa-masa pandemi seperti saat ini. Dari sinilah, pesantren memanfaatkan transaksi E-Bekal sebagai sebuah peluang yang akan meningkatkan stabilitas kegiatan pesantren. Program E-Bekal di Pesantren ini menjadi salah satu solusi untuk mengurangi efek negative dari penyalahgunaan uang saku santriwati, sehingga pengelolaan belanja satriwati lebih termenej oleh system dan juga dapat dikontrol oleh orang tua dirumah menggunakan handphone android.

\section{Daftar Pustaka}

Fadli, A. (2012). Pesantren: sejarah dan perkembangannya. EL-HIKAM: Jurnal Pendidikan Dan Kajian Keislaman, 5(1), 30-42

Adiyanti,ArsitaIka. (2015). "Pengaruh Pendapatan, Manfaat, Kemudahan Penggunaan, Daya Tarik Promosi, dan Kepercayaan Terhadap Minat Menggunakan Layanan E-Money". (Studi Kasus: Mahasiswa Universitas Brawijaya).

Aksami, Ni Made Dwi dkk. (2019). Analisis Minat Penggunaan Layanan E-Money Pada Masyarakat Kota Denpasar. E-Jurnal EP Unud, Vol. 8, No. 10: 2439-2470.

Bashori. (2017). Modernisasi Lembaga Pendidikan Pesantren. Jurnal Ilmu Sosial Mamangan, 6(1), 47-60

Djumransjah, H. M. (2016). Pendidikan Pesantren dan Kemandirian Santri. Jurnal IImu Pendidikan, 80-92.

Dzikrulloh, D. (2018). Optimalisasi Bisnis Pondok Peantren Dengan Elektronisasi Sistem Pembayaran Studi Kasus Pondok Pesantren Nurul Amanah Bangkalan. Wacana Equiliberium (Jurnal Pemikiran Penelitian Ekonomi), 1-8.

Faizin, d. (2015). Profil Pondok Pesantren Nurul Jadid. Probolinggo: Pustaka Nurja.

Fatimah, S. \&. (2019). TRANSFORMASI SISTEM PEMBAYARAN PESANTREN MELALUI E-MONEY DI ERA DIGITAL (Studi Pondok Pesantren Nurul Jadid). Jurnal Ekonomi dan Bisnis, 96-108.

Fitri, S. (2020). Pelatihan Pengelolaan E-Commerce pada Yayasan Pondok Pesantren Al-Hikmah Mangunreja Kabupaten Tasikmalaya . Jurnal Pengabdian Kepada Masyarakat, 273-279

Fatimah, S. \&. (2019). TRANSFORMASI SISTEM PEMBAYARAN PESANTREN MELALUI E-MONEY DI ERA DIGITAL (Studi Pondok Pesantren Nurul Jadid). Jurnal Ekonomi dan Bisnis, 96-108.

Ghufron, M. I. (2021). KOSMARA: Konsep Pengembangan Ekonomi Pesantren dan 
Pengendalian Pola Perilaku Konsumtif Santri di Pondok Pesantren Nurul Jadid. Al-Ulum Jurnal Pemikiran dan Penelitian ke Islaman, 113-127.

Izza. (2021). "Input Data. Probolinggo: Pustaka Nurja.

Ibnu Nawawi/Fathoni. (2016). Tebuireng Pelopori Transaksi Non-Tunai di Lingkungan Pesantren. NU Online.

Nadiyah, A. H. (2021). E-bekal E-BEKAL SEBAGAI MEDIA KONTROL BELANJA SANTRI PONDOK PESANTREN NURUL JADID. JATIM: Jurnal Aplikasi Teknologi Informasi dan Manajemen, 23-34.

Nadiyah, N. S. (2021). Pemahaman Aplikasi E-Bekal bagi Wali Asuh Santri sebagai Upaya Pencegahan Penyalahgunaan Uang Belanja Santri di Pesantren. GUYUB: Journal of Community Engagement, 126-140.

Nahrawi, A. F. (2021). description E-Bekal. Probolinggo: Pustaka Nurja.

Pranoto, \& Salsabila, S. S. (2018). Eksistensi Kartu Kredit Dengan Adanya Electronic Money (E-Money) Sebagai Alat Pembayaran Pembayaran Yang Sah. Privat Law, 6(1), 24-33

Rizal, S. S. (2021). Pelaksanaan Jaminan Fidusia Pada Pembiayaan Murabahah Di Bank Bni Syariah Kantor Cabang Probolinggo. Al-Intaj: Jurnal Ekonomi dan Perbankan Syariah, 10-20.

Suib, M. S. (2017). Sinergitas Peran Pondok Pesantren Dalam Peningkatkan Indek Pembangunan Manusia ( IPM ) di Indonesia, 1(2), 171-191
Syahroni, A. W., \& Ubaidi. (2018). Perancangan Aplikasi E-Money dan SMS Gateway untuk Pondok Pesantren di Daerah Madura. Jurnal LINK, 27(1)

Siahaan, M. (2020). Dampak Pandemi Covid-19 Terhadap Dunia Pendidikan. Jurnal Kajian Ilmiah, 1-3.

Tazkiyyaturrohmah, R. (2018). Eksistensi Uang Elektronik Sebagai Alat Transaksi Keuangan Modern. Eksistensi Uang Elektronik Sebagai Alat Transaksi Keuangan Modern. Muslim Heritage: Jurnal Dialog Islam dengan Realitas, 21-39.

W.Asuh. (2021). processing. Probolinggo: Pustaka Nurja.

Wahidah, E. Y. (2015). Studi Implementasi Tradisionalisasi dan Modernisasi Pendidikan di Pondok Pesantren. M U A D D I B, 5(2), 184-207

Yaqin, A. A. (2021). Pendampingan Ekonomi Pesantren Melalui Sentralisasi Transaksi Cost makan Santri di Pondok Pesantren Nurul Jadid Paiton. Panrannuangku Jurnal Pengabdian Masyarakat, 83-88.

Rodiyah, H. (2021, januari 2021). E-Bekal Santri di Wilayah Al-Hasyimiyah. (H. Qomariyah, Interviewer) 